\title{
PEMERIKSAAN ANTE NATAL CARE 4 KUNJUNGAN DENGAN KEHAMLAN RISIKO TINGGI PADA IBU HAMIL: TINJAUAN LITERATUR
}

\author{
Ante Natal Care Examination 4 Visits with High Risk of Pregnancy in Pregnant Women: \\ Literature Review
}

\section{Asri Kusyani ${ }^{1}$, Susanti ${ }^{2}$, Shelfi Dwi Retnani P. S ${ }^{1}$, Siti Fatimah ${ }^{3}$}

1. Dosen S1 Keperawatan STIKes Bahrul Ulum Jombang

2. Mahasiswa S1 Keperawatan STIKes Bahrul Ulum Jombang

3. Dosen D3 Kebidanan STIKes Bahrul Ulum Jombang

\section{Riwayat artikel}

Diajukan: 16 Oktober 2020

Diterima: 1 Maret 2021

\section{Penulis Korespondensi:}

- Susanti

- STIKes Bahrul Ulum Jombang

e-mail:

susantii822@gmail.com

\section{Kata Kunci:}

Antenatal Care, K4, Kehamilan Risiko Tinggi

\section{Abstrak}

Pendahuluan : Kehamilan risiko tinggi dianggap menjadi masalah yang besar dan harus segera ditangani dalam kesehatan masyarakat untuk menurunkan angka kematian ibu. Sebagian besar kehamilan dan persalinan akan mempunyai hasil yang menggebirakan yaitu ibu dan bayi lahir sehat. Namun ada ibu hamil yang akan menghadapi kegelisahan/kegawatan dengan tingkat ringan sampai berat yang dapat memberikan bahaya terjadinya ketidakpuasan, ketidaknyamanan, kesakitan, kecacatan maupun kematian bagi ibu dan bayinya. Penilaian terhadap pelaksanaan pelayanan kesehatan ibu hamil dapat dilakukan dengan melihat cakupan K4. Tujuan: penelitian ini untuk mengetahui hubungan pemeriksaan kehamilan K4 terhadap kehamilan risiko tinggi pada ibu hamil. Metode: Penelitian ini menggunakan metode literature review yang mengidentifikasi, menilai, dan menginterprestasikan seluruh temuan pada suatu topik penelitian. Sumber yang digunakan berupa artikel jurnal bereputasi baik nasional maupun internasioal dengan tema yang sudah ditentukan. Hasil: Berdasarkan hasil pencarian artikel yang sudah dipaparkan pemeriksaan antenatal care kurang dari empat kali berhubungan dengan peningkatan kehamilan risiko tinggi dan persalinan tindakan. Kesimpulan: pemeriksaan kehamilan K4 behubungan dengan kejadian kehamilan resiko tinggi pada ibu hamil. Oleh karena itu, deteksi dini kehamilan risiko tinggi perlu dilakukan di tingkat puskesmas untuk meningkatkan hasil ibu, kebidanan, dan neonatal. Saran bagi peneliti selanjutnya diharapkan untuk meneliti lebih lanjut tentang hubungan ANC K4 dengan kematian ibu dan janin.

\section{Abstract}

Background: High risk pregnancy is considered to be a big problem and must be addressed in public health to reduce maternal mortality. Most pregnancies and deliveries will have encouraging results, namely the mother and baby are born healthy. However, there are pregnant women who will face mild to severe anxiety / emergency that can present a danger of dissatisfaction, discomfort, pain, disability and death for the mother and her baby. Assessment of the implementation of health services for pregnant women can be done by looking at the $K 4$ coverage. Objective: The purpose of this study was to determine the relationship between $K 4$ antenatal care and high risk pregnancies in pregnant women. Method: This study uses a literature review method that identifies, assesses, and interprets all findings on a research topic. The sources used are in the form of reputable journal articles both nationally and internationally with predetermined themes. Results: Based on the results of the search for articles that explained that antenatal care examinations were less than four times associated with an increase in high-risk pregnancies and delivery actions. Conclusion: that $K 4$ pregnancy examination is associated with the incidence of high-risk pregnancy in pregnant women. Therefore, early detection of high risk pregnancies needs to be carried out at the puskesmas level to improve maternal, obstetric and neonatal outcomes. Suggestions for future researchers are expected to further investigate the relationship between ANC K4 and maternal and fetal mortality. 


\section{PENDAHULUAN}

Kehamilan resiko tinggi akan mempunyai outcome buruk yang berakibat pada kematian ibu maupun janin apabila tidak dilakukan tata laksanana secara tepat. Pada dasarnya kehamilan risiko tinggi disebabkan oleh empat faktor, yaitu faktor antenatal: hamil dengan kelainan letak, kehamilan ganda, gangguan pertumbuhan, hidramnion, preeklamsia. Faktor intrapartum: perdarahan ruptur uteri, plasenta previa, ketuban pecah dini, distress janin. Faktor obstetri: penyakit ibu dan janin, gangguan plasenta, gangguan tali pusat, komplikasi janin, penyakit neonatus dan kelainan genetic. Faktor umum: kemiskinan, pengetahuan, pendidikan rendah, adat istiadat, tradisi, kepercayaan, status gizi, sosial ekonomi yang rendah, kebersihan lingkungan, kesadaran untuk memeriksakan kehamilan secara teratur, dan fasilitas dan saranan kesehatan yang serba kekurangan, maka perlu dilakukan upaya optimal untuk mencegah atau menurunkan frekuensi ibu hamil yang berisiko tinggi dan penanganannya perlu segera dilakukan untuk menurunkan angka kematian ibu dan anak (Ayala: Manuaba, 2010). Rendahnya pengetahuan seseorang tentang pendidikan kesehatan akan mempengaruhi rendahnya kunjungan ibu hamil dalam memeriksakan kehamilannya, wanita yang berpendidikan akan lebih terbuka terhadap ide-ide baru dan perubahan untuk mendapatkan pelayanan kesehatan yang proposional karena manfaat pelayanan kesehatan akan mereka sadari sepenuhnya (Manuaba, 2010). Tenaga kesehatan juga memiliki peranan penting untuk meningkatkan kualitas pelayanan kesehatan yang maksimal kepada masyarakat agar masyarakat mampu meningkatkan kesadaran, kemauan dan kemampuan hidup sehat sehingga akan terwujud derajat kesehatan yang setinggi-tingginya (Manuaba, 2010). Ibu hamil juga mendapatkan pelayanan oleh tenaga kesehatan yang sesuai di fasilitas kesehatan setempat. Pelayanan ini dilakukan selama rentang usia kehamilan ibu yang jenis pelayanannya dikelompokkan sesuai usia kehamilan menjadi trimester pertama, trimester kedua, dan trimester ketiga

Penilaian terhadap pelaksanaan pelayanan kesehatan ibu hamil dapat dilakukan dengan melihat cakupan K4. Cakupan K4 merupakan. jumlah ibu hamil yang telah mendapatkan pelayanan antenatal sesuai SOP yang paling sedikit empat kali sesuai jadwal yang telah dianjurkan di tiap trimester, jika dibandingkan dengan jumlah sasaran ibu hamil di suatu wilayah kerja pada kurun waktu satu tahun. Indikator tersebut menunjukan akses pelayanan kesehatan terhadap ibu hamil serta tingkat kepatuhan ibu hamil dalam memeriksakan kehamilannya ke tenaga kesehatan (KEMENKES RI, 2018). Progam safe motherhood dilaksanakan dengan mempromosikan kesehatan ibu berfokus pada pengetahuan dan perilaku dengan memberikan pendidikan kesehatan pada masyarakat yang dapat meningkatkan penggunaan pelayanan antenatal care sehingga rendahnya cakupan K4 dapat teratasi dan tercapainya pelayanan ANC sesuai standart yang ditentukan (Janet dkk, 2011; buku Andriani, 2019). Bedasarkan pembahasan di atas maka peneliti tertarik untuk mengetahui " Hubungan Pemeriksaan K4 Dengan Kehamilan Risiko Tinggi Pada Ibu Hamil".

\section{METODE}

Metode dari tinjauan literature review ini menggunakan pedoman PRISMA Flow Chart dengan penelusuran artikel dari database Pubmed, DOAJ, ProQuest, Wiley, Sage, dan Google Schoolar. Pencarian artikel atau jurnal menggunakan keyword dan boolean operator (AND, OR NOT or AND NOT) yang digunakan untuk memperluas atau menspesifikasikan pencarian, sehingga mempermudah dalam penentuan artikel atau jurnal yang digunakan. Kata kunci dalam literature review ini disesuaikan dengan Medical Subject Heading (MeSH) yang dipaparkan pada tabel berikut Tabel 4.1 Kata Kunci Literature Review 


\section{HASIL PENELITIAN}

Prosedur pencarian dan seleksi artikel menggunakan enam database dengan kata kunci yang telah ditentukan, kemudian dilakukan filter secara bertahap sesuai kriteria inklusi dan eksklusi,

Gambar 4.1 Prosedur Pencarian dan Seleksi Artikel PRISMA Flowchart

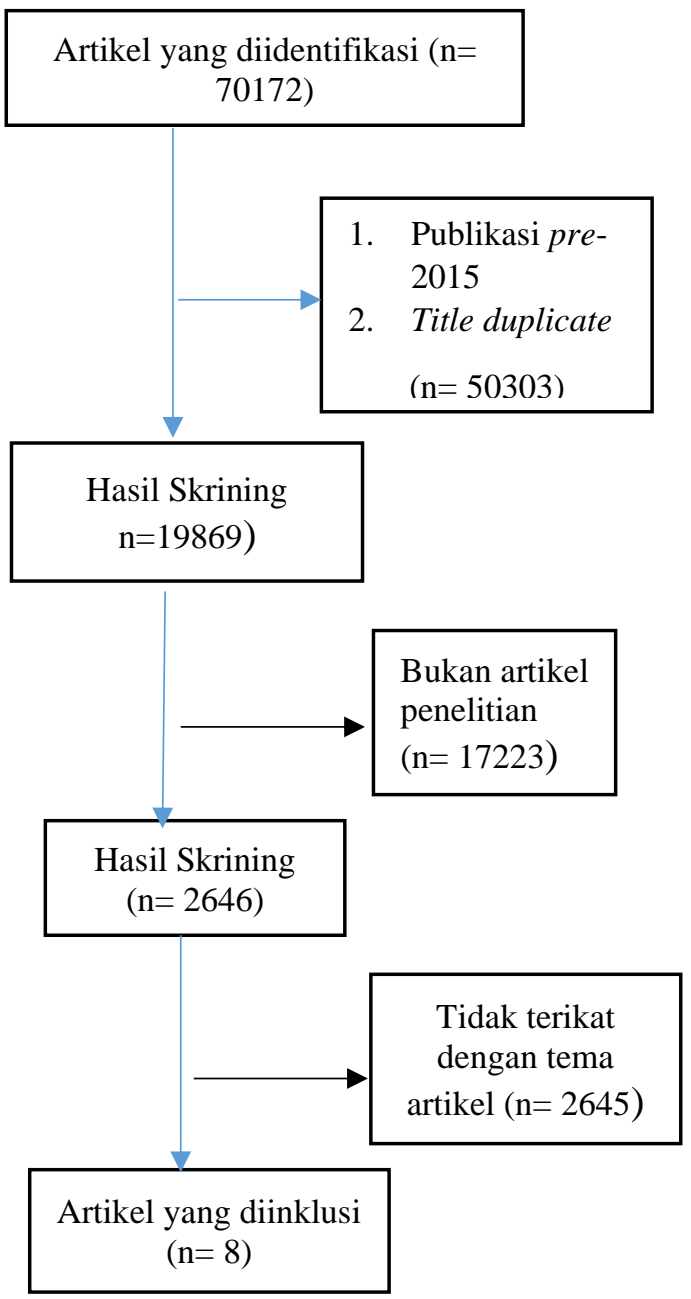

Figure 1: PRISMA Flow diagram

\begin{tabular}{llr}
\hline ANC K4 & $\begin{array}{l}\text { Kehamilan } \\
\text { Risiko Tinggi }\end{array}$ \\
\hline Antenatal Care & $\begin{array}{l}\text { High risk } \\
\text { Pregnancy }\end{array}$ \\
\hline OR & OR & \\
\hline K4 & $\begin{array}{l}\text { Risiko tinggi } \\
\text { kehamilan }\end{array}$ \\
\hline OR & OR & \\
\hline $\begin{array}{l}\text { Prenatal } \\
\text { Diagnosis }\end{array}$ & $\begin{array}{l}\text { Pregnancy } \\
\text { Complicatation }\end{array}$ \\
\hline
\end{tabular}

Hasil Pencarian yang sudah didapatkan diperiksa dan ditemukan 50303 artikes tidak relevan, pre-2015, title duplicate sehingga dikeluarkan, selanjutnya dilakukan screening berdasarkan abstrak $(\mathrm{n}=19869)$. Kemudian peneliti melakukan penelusuran full text $(\mathrm{n}=$ 2646) yang disesuaikan dengan tema literature review. Assessment yang dilakukan berdasarkan kelayakan terhadap kriteria inklusi dan eksklusi didapatkan sebanyak 10 artikel yang bisa digunakan dalam literature riview dengan 9 artikel membahas adanya hubungan ANC K4 dengan kehamilan risiko tinggi dan 1 artikel menjelaskan fakta tentang kepatuhan ANC dengan Kehamilan risiko tinggi 
Tabel 2: Hasil studi literatur intervensi keperawatan dalam proses hemodialisis

\begin{tabular}{|c|c|c|c|c|c|c|}
\hline Peneliti/tahun & Judul & Negara & Tujuan & Responden & Metode pengumpulan data & Hasil \\
\hline $\begin{array}{l}\text { (Tütün Yümin } \\
\text { et al., 2017) }\end{array}$ & $\begin{array}{l}\text { The effect of } \\
\text { foot plantar } \\
\text { massage on } \\
\text { balance and } \\
\text { functional } \\
\text { reach in } \\
\text { patients } \\
\text { with type II } \\
\text { diabetes }\end{array}$ & Turkey & $\begin{array}{l}\text { untuk menyelidiki } \\
\text { efek pijat plantar } \\
\text { kaki pada } \\
\text { keseimbangan dan } \\
\text { jangkauan } \\
\text { fungsional pada } \\
\text { pasien dengan } \\
\text { diabetes tipe II }\end{array}$ & $\begin{array}{l}38 \text { subjek yang } \\
\text { didiagnosis } \\
\text { dengan DM T2 }\end{array}$ & $\begin{array}{l}\text { Penelitian terdiri dari satu kelompok } \\
\text { yang dibagi berdasarkan umur yang } \\
\text { dibagi menjadi } \\
\text { tiga kelompok umur (40-54, 55-64, } \\
\text { dan } 65 \text { tahun ke atas), pengukuran } \\
\text { dilakukan sebelum dan sesudah } \\
\text { intervensi. Pretest dilakukan untuk } \\
\text { keseimbangan, mobilitas fungsional, } \\
\text { dan FRT. Tes diterapkan pada } \\
\text { individu dengan urutan di bawah ini: } \\
\text { setelah } 10 \text { menit } \\
\text { aplikasi pijat; TUG posttest; berdiri } \\
\text { satu kaki dengan mata terbuka- } \\
\text { tertutup; dan FRT, yang dilakukan } \\
\text { untuk menilai keseimbangan dan } \\
\text { jangkauan fungsional, diulang dalam } \\
\text { urutan yang sama. }\end{array}$ & $\begin{array}{l}\text { Analisis pasca intervensi } \\
\text { menemukan perbedaan statistik } \\
\text { pada penilaian TUG, FRT, dan } \\
\text { satu kaki } \\
\text { berdiri dengan mata terbuka atau } \\
\text { tertutup (untuk kanan dan kanan) } \\
\text { tes kaki kiri) }(\mathrm{p}<0,05) \text {. } \\
\text { Nilai TUG adalah } 7,5 \pm 2,1 \text { detik } \\
\text { sebelum dipijat, yang dikurangi } \\
\text { menjadi } 7,1 \pm 1,8 \text { setelah pijat. } \\
\text { Nilai FRT adalah } 29,3 \text { cm } \pm 7,2 \\
\text { sebelum pijat, yang meningkat } \\
\text { menjadi } 29,7 \pm 7,3 \text { setelah pijat. } \\
\text { Dengan cara yang sama, waktu } \\
\text { berdiri secara signifikan } \\
\text { meningkat setelah pijatan baik } \\
\text { untuk kiri dan kaki kanan dengan } \\
\text { kedua mata terbuka dan tertutup }\end{array}$ \\
\hline $\begin{array}{l}\text { (Chatchawan, } \\
\text { 2015) }\end{array}$ & $\begin{array}{l}\text { Effects of } \\
\text { Thai Foot } \\
\text { Massage on } \\
\text { Balance } \\
\text { Performance } \\
\text { in Diabetic } \\
\text { Patients with } \\
\text { Peripheral } \\
\text { Neuropathy: } \\
\text { A } \\
\text { Randomized } \\
\text { Parallel- } \\
\text { Controlled } \\
\text { Trial }\end{array}$ & Jepan & $\begin{array}{l}\text { Untuk menyelidiki } \\
\text { efek dari pijat kaki } \\
\text { Thailand } \\
\text { menyeimbangkan } \\
\text { kinerja pada } \\
\text { pasien diabetes } \\
\text { dengan neuropati } \\
\text { perifer fisik pasien } \\
\text { yang menjalani } \\
\text { HD }\end{array}$ & $\begin{array}{l}60 \text { pasien } \\
\text { dengan diabetes } \\
\text { tipe-2 direkrut } \\
\text { dan ditugaskan } \\
\text { secara acak ke } \\
\text { dalam pijat kaki } \\
\text { Thailand atau } \\
\text { kelompok } \\
\text { kontrol }\end{array}$ & $\begin{array}{l}\text { Pasien yang memenuhi kriteria } \\
\text { inklusi dibagi secara acak ke } \\
\text { kelompok pijat kaki Thailand atau } \\
\text { kontrol, kelompok menggunakan } \\
\text { alokasi acak blok bertingkat dengan } \\
\text { blok ukuran 2, 4, dan 6. Jenis kelamin } \\
\text { (pria atau wanita) dan kelompok } \\
\text { umur } \\
\text { (kelompok } 1=40-50 \text { tahun, } \\
\text { kelompok } 2=51-60 \text { tahun, dan } \\
\text { kelompok } 3=61-70 \text { tahun) juga } \\
\text { digunakan sebagai variabel } \\
\text { stratifikasi untuk mencapai perkiraan } \\
\text { keseimbangan usia dan karakteristik } \\
\text { jenis kelamin pasien. Skema } \\
\text { penugasan acak pra-hasil dibuat dan } \\
\text { ditutup dalam amplop oleh asisten }\end{array}$ & $\begin{array}{l}\text { Untuk efek langsung dari } \\
\text { pengobatan satu sesi pertama, } \\
\text { TUG untuk kelompok FM } \\
\text { meningkat secara signifikan dari } \\
\text { awal, sementara CON tidak } \\
\text { berubah. Namun, ketika } \\
\text { membandingkan } 2 \text { kelompok } \\
\text { setelah penyesuaian untuk tingkat } \\
\text { awal, TUG tidak berbeda secara } \\
\text { signifikan antara kelompok (p> } \\
\text { 0,05). Setelah perawatan } 2 \\
\text { minggu, kedua kelompok } \\
\text { meningkat secara signifikan dari } \\
\text { awal di semua parameter. Penilain } \\
\text { TUG untuk kelompok FM lebih } \\
\text { cepat dari pada untuk CON } \\
\text { sebagai 1,13 detik (95\% CI 0,76- } \\
\text { 1,50 detik, p <0,001). Selain itu, }\end{array}$ \\
\hline
\end{tabular}




\begin{tabular}{|c|c|c|c|c|c|c|}
\hline Peneliti/tahun & Judul & Negara & Tujuan & Responden & Metode pengumpulan data & Hasil \\
\hline & & & & & $\begin{array}{l}\text { peneliti yang tidak terlibat dalam } \\
\text { proses perawatan dan hasil penilaian) }\end{array}$ & $\begin{array}{l}\text { TUG berkorelasi dengan variabel } \\
\text { pra-tes dari MTP } 1 \text { kiri dan kanan } \\
\text { dalam ekstensi (kiri; } r=0,39, p= \\
0,0023 \text { dan kanan; } r=0,35, p= \\
0,0064) \text {. OLS dengan kondisi mata } \\
\text { terbuka juga berkorelasi dengan } \\
\text { SWMT (kiri; } r=0,31, p=0,0116 \\
\text { dan kanan; } r=0,32, p=0,0085 \text { ). }\end{array}$ \\
\hline $\begin{array}{l}\text { (Park et al., } \\
\text { 2017) }\end{array}$ & $\begin{array}{l}\text { Application } \\
\text { of massage } \\
\text { for ankle joint } \\
\text { flexibility } \\
\text { and balance }\end{array}$ & Korea & $\begin{array}{l}\text { untuk menguji } \\
\text { efek dari } \\
\text { pemijatan otot } \\
\text { betis pada } \\
\text { fleksibilitas } \\
\text { pergelangan kaki } \\
\text { dan keseimbangan }\end{array}$ & $\begin{array}{l}32 \text { mahasiswa } \\
\text { yang sehat, } \\
\text { dibagi menjadi } \\
\text { dua kelompok } \\
\text { sesuai dengan } \\
\text { metode pijat. }\end{array}$ & $\begin{array}{l}\text { Para siswa secara acak ditugaskan ke } \\
\text { dua kelompok intervensi (pijat } \\
\text { kelompok A: effleurage, tapotement } \\
\text { dan tekanan) teknik atau kelompok B } \\
\text { pijat: teknik effleurage, gesekan dan } \\
\text { petrissage). Pemijatan selama lima } \\
\text { menit diberikan pada masing-masing } \\
\text { betis yang memberikan total } 10 \\
\text { menit. Sebelum dipijat, subjek } \\
\text { melakukan latihan pendakian yang } \\
\text { ringan naik dan turun gedung lima } \\
\text { lantai sekali, yang dianggap sebagai } \\
\text { kegiatan sehari-hari biasa, diikuti } \\
\text { dengan istirahat lima menit. } \\
\text { Penelitian } \\
\text { subyek mengenakan celana pendek } \\
\text { dan menerima pijatan dalam posisi } \\
\text { tengkurap. Uji jangkauan fungsional } \\
\text { (FRT) dilakukan untuk mengukur } \\
\text { fleksibilitas dan keseimbangan } \\
\text { pergelangan kaki baik sebelum dan } \\
\text { sesudah intervensi, dan tes satu kaki } \\
\text { yang dimodifikasi (OLST) dilakukan } \\
\text { untuk mengukur keseimbangan statis }\end{array}$ & $\begin{array}{l}\text { Kelompok A secara statistic } \\
\text { perbedaan nilai OLST sebelum } \\
(6,24 \pm 1,7 \text { detik) dan setelah }(9,24 \\
\pm 2,3 \text { detik) intervensi pijatan saat } \\
\text { mendukung tubuh di kaki kiri (p } \\
<0,01) \text { Kelompok } \\
\text { menunjukkan perbedaan yang } \\
\text { signifikan secara statistik di kedua } \\
\text { sisi (p <0,01). Tidak ada } \\
\text { perbedaan yang signifikan secara } \\
\text { statistik dalam nilai OLST } \\
\text { sebelumnya }(6,24 \pm 1,7 \text { detik) dan } \\
\text { setelahnya ( } 6,11 \pm 1,9 \text { detik) di } \\
\text { kaki kanan. ada kelompok Pijat A, } \\
\text { nilai FRT meningkat dari } 35,46 \pm \\
5,3 \text { cm sebelum berolahraga } \\
\text { hingga } 41,61 \pm 5,9 \text { cm setelah } \\
\text { dipijat. dan Pada kelompok Pijat } \\
\text { B, nilai FRT meningkat dari } 35,72 \\
\pm 5,0 \text { cm sebelum berolahraga } \\
\text { menjadi } \\
40,49 \pm 5,7 \text { cm setelah dipijat. }\end{array}$ \\
\hline $\begin{array}{l}\text { (Vaillant et al., } \\
\text { 2009) }\end{array}$ & $\begin{array}{l}\text { Massage and } \\
\text { mobilization } \\
\text { of the feet } \\
\text { and ankles in } \\
\text { elderly } \\
\text { adults; effect }\end{array}$ & Prancis & $\begin{array}{l}\text { untuk } \\
\text { membandingkan } \\
\text { dampak pijat dan } \\
\text { mobilisasi kaki } \\
\text { dan pergelangan } \\
\text { kaki versus }\end{array}$ & 28 lansia & $\begin{array}{l}\text { Kriteria inklusi yaitu Lansi di atas } 65 \\
\text { tahun dan kemampuan berjalan } 10 \mathrm{~m} \text {. } \\
\text { Kriteria ekslusi } \\
\text { dikeluarkan jika mereka memiliki } \\
\text { gangguan kognitif yang parah, } \\
\text { dengan cepat penyakit progresif atau }\end{array}$ & $\begin{array}{l}\text { Hasilnya menunjukkan perubahan } \\
\text { yang baik untuk ketiga kelompok. } \\
\text { Perubahan rata-rata (SD) dalam } \\
\text { tes OLB adalah } 1,1 \quad(1,7) \text { untuk } \\
\text { MMP dan }\end{array}$ \\
\hline
\end{tabular}


Jurnal Ilmiah Keperawatan (Scientific Journal of Nursing), Vol 7, No 1, Tahun 2021

\begin{tabular}{|c|c|c|c|c|c|c|}
\hline Peneliti/tahun & Judul & Negara & Tujuan & Responden & Metode pengumpulan data & Hasil \\
\hline & $\begin{array}{l}\text { on clinical } \\
\text { balance } \\
\text { performance }\end{array}$ & & $\begin{array}{l}\text { plasebo pada } \\
\text { kinerja } \\
\text { keseimbangan } \\
\text { fungsional, dan } \\
\text { yang kedua } \\
\text { meningkatkan } \\
\text { pemahaman } \\
\text { tentang peran yang } \\
\text { dimainkan oleh } \\
\text { input ekstremitas } \\
\text { bawah distal } \\
\text { dalam kontrol } \\
\text { keseimbangan } \\
\text { selama kegiatan } \\
\text { fungsional }\end{array}$ & & $\begin{array}{l}\text { terminal, penyakit akut atau kronis } \\
\text { tidak stabil penyakit, infark miokard } \\
\text { atau fraktur ekstremitas bawah, } \\
\text { dalam enam bulan sebelum inklusi. } \\
\text { dua sesi diselenggarakan: satu } \\
\text { melibatkan pijatan dan mobilisasi } \\
\text { dan yang lainnya, aplikasi plasebo. } \\
\text { Untuk menghindari efek bawaan, } \\
\text { setidaknya satu Minggu memisahkan } \\
\text { dua sesi yang dilakukan dalam urutan } \\
\text { acak. Pengukuran diperoleh segera } \\
\text { sebelum dan sesudah masing-masing } \\
\text { protokol ini. Tes fungsional, semua } \\
\text { dilakukan dalam urutan berikut, } \\
\text { termasuk tes OLB, tes TUG } \\
\text { dan uji LR. }\end{array}$ & $\begin{array}{l}0,4(1,2) \mathrm{s} \text { untuk PP }(\mathrm{p}<0,01) \\
\text { Mean (SD) berubah dalam tes } \\
\text { TUG } \\
0,9(2,6) \text { untuk MMP dan } 0,2(1,2) \\
\text { untuk PP }(\mathrm{p}<0,05) \text {. } \\
\text { Sebaliknya, peningkatan dalam uji } \\
\text { LR tidak signifikan } \\
\text { berbeda antara MMP }(1,32,3 \mathrm{~cm}) \\
\text { dan PP }(0,81,3 \mathrm{~cm})\end{array}$ \\
\hline $\begin{array}{l}\text { (Hemmati, } \\
\text { Rojhani- } \\
\text { Shirazi, \& } \\
\text { Ebrahimi, } \\
\text { 2016) }\end{array}$ & $\begin{array}{l}\text { Effects of } \\
\text { Plantar } \\
\text { Flexor } \\
\text { Muscle Static } \\
\text { Stretching } \\
\text { Alone and } \\
\text { Combined } \\
\text { With } \\
\text { Massage on } \\
\text { Postural } \\
\text { Balance }\end{array}$ & Iran & $\begin{array}{l}\text { Untuk } \\
\text { mengevaluasi dan } \\
\text { membandingkan } \\
\text { efek peregangan } \\
\text { dan terapi } \\
\text { kombinasi } \\
\text { (peregangan dan } \\
\text { pijat) pada } \\
\text { keseimbangan } \\
\text { postural pada } \\
\text { orang berusia } 50 \\
\text { hingga } 65 \text { tahun }\end{array}$ & 23 Responden & $\begin{array}{l}\text { Kriteria eksklusi } \\
\text { adalah nyeri pinggang, penggunaan } \\
\text { alkohol dalam } 24 \text { jam sebelum } \\
\text { intervensi, riwayat operasi di } \\
\text { ekstremitas bawah, disfungsi } \\
\text { vestibular (dengan diagnosis dokter) } \\
\text { atau gangguan keseimbangan } \\
\text { (seperti ketidakstabilan pergelangan } \\
\text { kaki), dan riwayat masalah } \\
\text { neurologis. Untuk mengukur } \\
\text { keseimbangan postur tubuh, para } \\
\text { peserta berdiri tanpa alas kaki dengan } \\
\text { kekuatan ditetapkan pada tingkat } \\
\text { sampel 100 Hz di posisi netral dan } \\
\text { mereka diminta untuk bergerak } \\
\text { sesedikit mungkin. Tes dilakukan } \\
\text { dalam tiga kondisi (tidak ada } \\
\text { intervensi, peregangan, dan } \\
\text { intervensi gabungan) dengan mata } \\
\text { buka dan tutup. Setiap tes (30 detik } \\
\text { durasi) diulang tiga kali dengan } 10 \\
\text { detik terletak di antara uji coba. Para }\end{array}$ & $\begin{array}{l}\text { Ada perbedaan yang signifikan } \\
\text { antara kelompok yang tidak diberi } \\
\text { intervensi, kelopok intervensi } \\
\text { (peregangan) maupun kelompok } \\
\text { gabungan (peregangan dan pijat) } \\
\text { dengan nilai p }<0,05 \\
\text { Perpindahan mediolateral } \\
\text { dan kecepatan pusat tekanan } \\
\text { (COP) meningkat setelah } \\
\text { dilakukan peregangan maupun } \\
\text { intervensi gabungan (peregangan } \\
\text { dan pijat). } \\
\text { Bahkan, } \\
\text { perpindahan dan kecepatan } \\
\text { meningkat lebih besar setelah } \\
\text { intervensi gabungan dari pada } \\
\text { setelah peregangan sendiri }\end{array}$ \\
\hline
\end{tabular}


Jurnal Ilmiah Keperawatan (Scientific Journal of Nursing), Vol 7, No 1, Tahun 2021

\begin{tabular}{|c|c|c|c|c|c|c|}
\hline Peneliti/tahun & Judul & Negara & Tujuan & Responden & Metode pengumpulan data & Hasil \\
\hline & & & & & $\begin{array}{l}\text { peserta menerima kedua peregangan } \\
\text { statis itu sendiri dan intervensi } \\
\text { gabungan } \\
\text { pemijatan) } \\
\text { (peregangan dara acak pada hari } \\
\text { vang sama. }\end{array}$ & \\
\hline $\begin{array}{l}\text { (Vaillant et al., } \\
\text { 2008) }\end{array}$ & $\begin{array}{l}\text { Effect of } \\
\text { manipulation } \\
\text { of the feet } \\
\text { and ankles on } \\
\text { postural } \\
\text { control in } \\
\text { elderly adults }\end{array}$ & 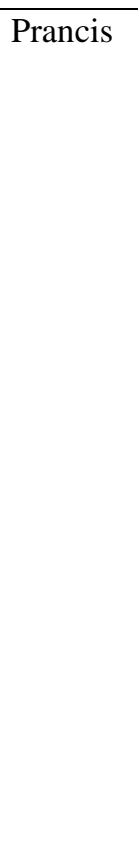 & $\begin{array}{lr}\text { untuk menyelidiki } \\
\text { efek terapi } \\
\text { manipulasi kaki } \\
\text { dan pergelangan } \\
\text { kaki pada kontrol } \\
\text { postural selama } \\
\text { berdiri tenang } \\
\text { pada orang tua } \\
\text { orang dewasa }\end{array}$ & 17 responden & $\begin{array}{l}\text { Kriteria ekslusi adalah lansia yang } \\
\text { mengalami masalah } \\
\text { muskuloskeletal, cacat pada sistem } \\
\text { sensorik perifer dari ekstremitas } \\
\text { bawah,patologi vaskular, gangguan } \\
\text { neurologis atau gangguan vestibular. } \\
\text { Subjek berdiri tanpa alas kaki di } \\
\text { platform kekuatan, kaki bergabung, } \\
\text { dan diminta bergerak sesedikit } \\
\text { mungkin, dengan mata terbuka. Pra } \\
\text { test berfungsi sebagai sesi kontrol. } \\
\text { Pada sesi Post-test, pengukuran } \\
\text { dilakukan segera setelah manipulasi } \\
\text { terapeutik pada kaki dan pergelangan } \\
\text { kaki. }\end{array}$ & $\begin{array}{l}\text { Hasilnya menunjukkan bahwa } \\
\text { terapi intervensi tidak } \\
\text { mempengaruhi pemindahan AP } \\
\text { COP segera setelah penekanan visi } \\
\text { dengan nilai p }>0,05 \text { dan Untuk } \\
\text { perpindahan ML dan AP COP, } \\
\text { hasil menunjukkan tidak ada efek } \\
\text { dari Seri (Ps }>0,05) \text {, dan tidak ada } \\
\text { interaksi Seri } \times \text { Kerangka } \\
\text { temporal (M> 0,05). Namun } \\
\text { Analisis perpindahan AP COP } \\
\text { menunjukkan signifikan interaksi } \\
\text { Sesi } \times \text { Kerangka temporal (F (1, } \\
16)=5.48, P<0,05) \text {. Uji ANOVA } \\
\text { juga menunjukkan efek utama } \\
\text { Temporal bingkai (F (1, 16) }= \\
4,53 \text {, P <0,05) dan Sesi (F }(1,16) \\
=11,07, \mathrm{P}<0,01) \text {. Pijat kaki dapat } \\
\text { meningkatkan keseimbangan } \\
\text { lansia meskipun diperkirakan } \\
\text { dalam waktu yang cepat }\end{array}$ \\
\hline
\end{tabular}




\section{PEMBAHASAN}

Berdasarkan hasil pencarian artikel yang sudah dipaparkan menunjukan adanya hubungan antara pemeriksaan $\mathrm{k} 4$ dengan kehamilan risiko tinggi, pemeriksaan antenatal care $<4$ kali berhubungan dengan peningkatan kehamilan risiko tinggi dan persalinan tindakan. Kurangnya pemeriksaan antenatal berhubungan dengan score apgar yang rendah, sehingga pemeriksaan antenatal care yang adekuat merupakan faktor penting dalam menurunkan angka kematian ibu dan anak. Antenatal Care adalah upaya preventif program pelayanan kesehatan obstetrik untuk optimalisasi luaran maternal dan neonatal melalui serangkaian kegiatan pemantauan rutin selama kehamilan (Sarwono, 2018). Pelayanan kesehatan pada ibu hamil tidak dapat dipisahkan dengan pelayanan persalinan, pelayanan nifas dan pelayanan kesehatan bayi baru lahir. Kualitas pelayanan antenatal care mempengaruhi kesehatan ibu hamil dan janin, ibu bersalin dan bayi baru lahir serta ibu nifas. Adanya hubungan yang signifikan antara pemeriksaan kehamilan K4 dengan kejadian kehamilan risiko tinggi karena untuk menghindari resiko komplikasi pada kehamilan dan persalinan, anjurkan setiap ibu hamil untuk melakukan kunjungan antenatal komprehensif yang berkualitas minimal empat kali, termasuk minimal satu kali kunjungan diantar suami/pasangan atau anggota keluarga (KEMENKES, 2018). Idealnya bila tiap wanita hamil mau memeriksakan kehamilannya untuk mendeteksi kelainankelainan yang mungkin ada atau akan timbul pada kehamilan tersebut lekas diketahui, dan segera dapat diatasi sebelum berpengaruh tidak baik terhadap kehamilan tersebut dengan melakukan pemeriksaan antenatal care. Apabila seorang ibu hamil memiliki pengetahuan yang lebih tentang resiko tinggi kehamilan maka kemungkinan besar ibu akan berpikir untuk menentukan sikap mencegah menghindari dan mengatasi masalah resiko kehamilan. Pelayanan antenatal merupakan merupakan pelayanan kesehatan oleh tenaga kesehatan terlatih untuk ibu selama masa kehamilannya, dilaksanakan sesuai dengan standar pelayanan antenatal yang ditetapkan dalam Standar Pelayanan Kebidanan (SPK).

\section{KESIMPULAN DAN SARAN}

Penggunaan perawatan antenatal yang tidak proporsional sesuai dengan tingkat risiko kehamilan menunjukan kebutuhan untuk penjadwalan yang lebih baik, sehingga pemeriksaan $\mathrm{K} 4$ sangat penting untuk dilakukan agar risiko tinggi kehamilan dapat diberikan intervensi yang diharapkan, artinya ada hubungan antara pemeriksaan kehamilan K4 dengan kejadian kehamilan resiko tinggi pada ibu hamil. Oleh karena itu, deteksi dini kehamilan risiko tinggi perlu dilakukan di tingkat puskesmas untuk meningkatkan hasil ibu, kebidanan, dan neonatal. Saran bagi peneliti selanjutnya diharapkan hasil penelitian ini dapat digunakan sebagai data dasar untuk meneliti lebih lanjut tentang hubungan ANC K4 dengan tingkat kepuasan ibu hamil dalam menghadapi persalinan.

\section{DAFTAR PUSTAKA}

\section{Buku}

Andriani, R. 2019. Pencegahan Kematian Ibu Saat Hamil dan Melahirkan. Yogyakarta: CV. Budi Utama

Manuaba dkk. (2010). Pengantar Kuliah Obstetri.Jakarta: ECG

RI K. Profil Kesehatan Indonesia 2018. Jakarta: Kementrian Kesehatan RI; 2018

Sarwono, P. (2018). Ilmu Kebidanan. Jakarta: PT. Bina Pustaka Sarwono Prawirohardjo

\section{Jurnal}

Astutik, Y.R., Rusdianawat, T. 2017. Kepatuhan Antenatal Care Ibu Hamil Resiko Tinggi dengan Ketepatan Rujukan Di Desa Sepawon Kecamatan Plosoklaten. Journal of Chemical Information and Modeling, 53(9), 1689-1699. 
https://doi.org/10.1017/CBO97811

07415324.004

Bukit, R. (2016). World Health Statistics. Dunia: WHO. 4(1), 199-203. https://doi.org/10.22216/jen.v4i1.21 01

Duha, Y. (2019). Hubungan Pengetahuan dan Sikap Ibu Tentang Risiko Tinggi Kehamilan dengan kelengkapan antenatal care (ANC) Di Klinik Siti Hajar R. Amd. Keb

Fairuza, F., St, S., \& Kes, M. (2019). Hubungan Frekuensi ANC dengan Pemgetahuan Resiko Tinggi Kehamilan Di Puskesmas Kilasah Kota Serang. 1(1), 122-130

Mahendra, A. D., Hidajaturrokhmah, N. Y., \& Anggraeni, S. (2019). Analisis Kepatuhan Antenatal Care (Anc) Terhadap Kejadian Komplikasi Kehamilan Di Puskesmas Tiudan Kecamatan Gondang Kabupaten Tulungagung. Jurnal Ilmiah Ilmu Keperawatan Indonesia, 9(04), 673-680.

https://doi.org/10.33221/jiiki.v9i04. 356

Majella, G.M., Sarveswaran dkk.(2018). Social Support and Self - Care Behavior Study. 16.https://doi.org/10.4103/jehp.jehp

Meyliya, Q., Hidayah, S.N. (2016). Persepsi Ibu Hamil Tentang Kehamilan Resiko Tinggi Dengan Kepatuhan Melakukan Antenatal Care Di Desa Begawat Kecamatan Bumijawa Kabupaten Tegal. Seminar Nasional IPTEK Terapan (SENIT) 2017 ISSN: 2579-9045 Tegal - Indonesia, 15-17 Mei 2017 ISBN: 978-602-74355-1-3. 201.

Nuraisya, W. (2018). Deteksi Risiko Tinggi Kehamilan Pada Pelayanan ANC Terpadu di Puskesmas Bendo Kabupaten Kediri. Jurnal Kesehatan Andalas, $\quad 7(2), \quad 240$. https://doi.org/10.25077/jka.v7.i2.p 240-245.2018.
Pattiasina, J. A., Lima, F. V. I. De, \& Polpoke, S. U. M. (2019). HUBUNGAN KETERATURAN ANTENATAL CARE DENGAN TINGKAT KEHAMILAN RISIKO TINGGI PADA IBU HAMIL DI DUSUN KAMPUNG BARU - DESA KAWA Puskesmas Kilang Ambon, 2 Fakultas Kedokteran Universitas Pattimura, Puskesmas Bai Bula Corresponding

Wahidamunir. (2009). Hubungan tingkat pengetahuan ibu hamil tentang resiko tinggi kehamilan dengan kepatuhan kunjungan. 2, 174-182.

Yeoh, P. L., Hornetz, K., \& Dahlui, M. (2016). Antenatal care utilisation and content between low-risk and high-risk pregnant women. PLoS ONE, 11(3), 1-18. https://doi.org/10.1371/journal.pon e. 0152167 